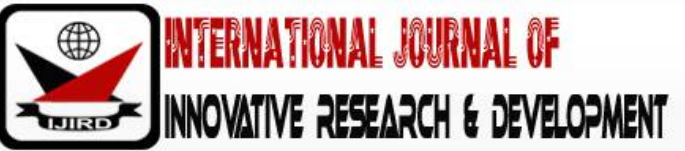

ISSN $2278-0211$ (Online)

\section{Educational Leadership for Institutional Best \\ Practices and Goal Achievement among Secondary \\ Schools in Enugu State, Nigeria}

Obineme, Patience $\mathbf{0 .}$
Lecturer, Department of Educational Management and Policy,
Nnamdi Azikiwe University Awka, Nigeria
Dr. Ven. John Nweke
Lecturer, Department of Educational Management and Policy,
Nnamdi Azikiwe University Awka, Nigeria
Chime, Gladys O.
Lecturer, Department of Educational Management and Policy,
Nnamdi Azikiwe University Awka, Nigeria
Loveline B Ekweogu
Lecturer, Department of Educational Management and Policy,
Nnamdi Azikiwe University Awka, Nigeria

\begin{abstract}
:
The quest for better leadership in Nigerian secondary schools has also been the vision of stakeholders in education who have invested hugely for the success of our education system. This study therefore examines educational leadership for institutional best practices and goal achievement among secondary schools in Enugu state. The study adopted the descriptive survey design for the research. Area of study is Enugu state. The population consist of 6321 secondary school teachers in Enugu state. Multi stage, stratified proportionate and purposive sampling was employed in selecting samples for the study. The instrument used for the study was a 15-item questionnaire drafted by the researcher. The instruments which has three sections were validated by three experts. The reliability coefficient was determined using Cronbach Alpha reliability coefficient technique which gave coefficient of 0.73. Arithmetic Mean and standard deviation were used as analysis tool. While t-test was used to test the hypothesis. Findings show that to a high extent, leaders among secondary schools in Enugu state were democratic. They share duties and involve their teachers on academic activities. It was also revealing that they were not autocratic, nor lazy in their primary responsibilities. Based on these findings, it was recommended that to a high extent, leaders and teachers in secondary schools should be constantly undergo retraining exercise on implementation of educational leaderships in schools to enhance best practices and achievement of goals in schools.
\end{abstract}

Kevwords: Educational leadership, institutional best practices and achievement

\section{Introduction}

Education all over the world is seen as the corner stone of development and the major social services which the government of any nation, communities, parents and philanthropic organizations give to their children. It forms the basis for literacy, skill acquisition, technological development and the ability to harness the natural resources of the environment. In line with the above statement, Federal Government of Nigeria (FGN) (2004) adopted education as an instrument par excellence for effecting national development. FGN (2004) maintained that the success of any system of education is hinged on proper planning, effective administration and adequate financing. Eze in Okeze, Okpe and Ngwakwe (2018) also considered education as a potent instrument for social, moral, economic, technological and scientific development in Nigeria.

Education as one of the most building blocks for human development has a formative effect on the mind, character and accelerates the development of knowledge, skills, and attitude (Alumode, 2012). In the views of Temesgen (2017), education is a crucial instrument that contributes to all aspects of the country's progress. It has a great effect on students' life in establishing their sense of citizenship and preparing them for the world of work. However, realizing the potential of a student is highly dependent on the quality of leadership in educational institutions. This means that educational system which is pride to nations needs to be led or else their likelihood that goals might not be realized. Leadership refers to the ability to inspire confidence and support among followers who are expected to achieve organizational goals. Schermerhorn, Hunt and Osborn (2000) defines leadership as a case of interpersonal influence that get individuals, or 
groups of people to do what the leader wants to be done. Related to this is Sashkin and Sashkin in Kamurua (2013) define leadership as the art of transforming people and organization with the aim of improving the organisation. Cambridge Assessment International Education (2017) defined Leadership as an intentional influence which is exerted by one person or a group, over other people or groups, to structure the activities and relationships in a group or organization. Leaders in this perspective define the task and explain why the job is being done; they oversee followers' activities and ensure that followers have what they need in terms of skills and resources to do the job. These kinds of leaders develop a relationship between themselves and their followers; they align, motivate and inspire the followers to foster productivity.

Leadership does not occur in isolation, in occurs in institutions, education included. Educational leadership as a separate entity refers to the process of coordinating activities of the school to achieve certain goals. Wikipedia (2020) defined educational leadership as the process of enlisting and guiding the talents and energies of teachers, pupils, and parents toward achieving common educational aims. In the views of Aurora (2013), educational leadership is a term that has to do mainly with the duties and responsibilities of the leadership team in order to improve school management, as well as students' achievement. In order to enhance and improve school leadership, the person in charge with school administration, comprising the principal, deputy manager, teachers, have to attend effective training to be provided with updated and useful data that will allow them to identify the strong and weak points in learning and teaching, as well as the auxiliary activities leading to it.

Since it has been established that educational leadership is non-separable from schools, The School remains the formal place where children may grow and develop academically when they are properly guided. According to Akanni (2019), Schools are established for the purpose of teaching and learning. Educational leadership also plays vital role in secondary schools. The Federal Government of Nigeria (FGN) as cited in Ezenwekwe (2013) in her National Policy on Education (NPE) defined secondary education as the education children receive after primary education and before the tertiary stage. Secondary school is the bridge between the primary and tertiary levels.

According to the Mauritian Ministry of Education and Human Resources (2014), the secondary school provides an education that enables the fulfillment of the four pillars of the Delors Report, namely learning to know, learning to do, learning to be, and learning to live together. It should also provide the adolescent student with the necessary skills that allow him/her to adjust easily and smoothly to the rapid physical, emotional, mental and social changes (Garcia \& Santiago, 2017).

Louis (2017) asserts that the school should also teach the five components of the Social Emotional Learning (SEL), namely self-awareness, social awareness, self-management, decision-making and relationship management to adolescent students. These are the fundamental skills that they must learn, develop and practice in order to develop and manifest positive social-emotional behaviour.

As contained in the document, the goals of secondary education according to Federal Government of Nigeria in Ezenwekwe (2013) shall be to: Provide all primary school leavers with the opportunity for a higher, irrespective of sex, social status, and religious or ethnic background; Offer diversified curriculum to cater for the differences in talents, opportunities and future roles; Provide trained manpower in the applied science, technology and commerce at subprofessional grades; Develop and promote Nigerian languages, arts and culture in the context of world's cultural heritage; Inspire students with a desire for self-improvement and achievement of excellence; Foster National unity with an emphasis on the common tries that unite us in our diversity; Raise a generation of people who can think for themselves, respect the views and feelings of others, respect the dignity of labour, appreciate those values specified under our broad national goals and live as good citizens; Provide technical knowledge and vocational skills necessary for agricultural, industrial, commercial and economic development.

One of the underline principles is that secondary schools should be able to provide and promote Nigerian languages, arts and culture in the context of world's cultural heritage. This could be best achieved through a wellstructured curriculum with the help of the school administrators such as the school principals leading the school to direction of success.

Authorities such as Anuna (2010) and Kanuruo (2013) have enumerated numerous educational leaderships that have contributed to the progress of educational leadership and goal achievement in our secondary schools. For instance,

Pont, Nusche, \& Moorman in Kamurua (2013) admitted that if institutional goals may be achieved, schools should be guided by a leader who ensures that policies are systematically implemented. Davis, Darling-Hammond, La Pointe and Myerson (2005) in Kamurua (2013) held that despite the above mentioned circumstances, school principals or head teachers are still expected to function as educational visionaries, in structural and curriculum, assessment experts, disciplinarian, community builders, public relations experts, budget analysts, facility managers, special programs administrators and expert of legal, contractual and policy mandates and initiatives. They are then again expected broker the often-conflicting interests of parents, teachers, students, district office officials, union and state and federal agencies and they need to be sensitive to the widening rage of student's needs.

Having come across some educational leaderships by different authorities, the researcher discovered that their studies were carried outside Enugu state and this, makes the researcher doubt educational leadership to be adopted among secondary schools in Enugu state to enhance best practices and achieve stated goals. The researcher became worried about this and thus, decided to delve into a study of this kind.

\subsection{Statement of the Problem}

There are certain observed occurrences such as laisser-faire attitude and autocracy among some secondary school principals that have made some stakeholders in education doubt their credibility and ability to drive home certain worthy practices and educational goals at this level of education. The leadership qualities of some of these school heads have been 
questions because as observed, most of their leadership virtues are poor and less educational, thus, very weak drive home educational achievements. There is no doubt that the leadership established in schools influences both the teacher and the learner which sometimes leads to poor performances both on teachers and students. The researcher observed that there are lapses among some secondary school leaders in terms of coordinating academics, teacher-teacher as well a teacher principal relationship and these affects the achievement of educational goals in schools. The researcher, on prior observations of these gaps, thought it wise that it needs to be filled. Therefore, the problem of this research is to examine educational leadership suitable for institutional best practices and goal achievement among secondary schools in Enugu state.

\subsection{Purpose of the Study}

The general purpose of the study is to examine educational leadership for institutional best practices and goal achievement among secondary schools in Enugu state. Specifically, the study seeks to;

- Find out the extent democratic leadership enhance institutional practice and goal achievement among secondary schools.

- Examine the extent autocratic leadership enhance institutional practice and goal achievement among secondary schools.

- Investigate the extent laisser-fair leadership enhance institutional practice and goal achievement among secondary schools?

\subsection{Research Questions}

The following research questions guided this study

- To what extent does democratic leadership enhance institutional practice and goal achievement among secondary schools?

- To what extent does autocratic leadership enhance institutional practice and goal achievement among secondary schools?

- To what extent does laisser-fair leadership enhance institutional practice and goal achievement among secondary schools?

\subsection{Research Hypothesis}

- $\mathrm{H}_{0}$ : Opinions of male and female teachers do not significantly differ on extent leadership enhance institutional practice and goal achievement among secondary schools

\section{Method}

This study adopted the descriptive survey design for the research. Area of study for this research is Enugu state. Population of the study comprises of 6321 secondary school teachers in Enugu state out of which 1078 are male while 5243 females. The multi stage sampling technique was adopted for the study. firstly, the researcher identified with the education zones in the state which amounts six. From these six zones, the researcher proportionately selected three secondary schools from each education zones making up to 18 secondary schools selected for the study. stage two, trough simple random sampling, the researcher selected 12 secondary school teachers from each of the schools, this amounted up to 216 number of teachers randomly selected which later reduced to 173 after retrieving the questionnaire. The researcher purposively selected teachers for this study because they stand a better chance to report educational leadership virtues of their principals and how best these virtues actualize educational goals in their various schools.

The instrument used for the study was a 15-item questionnaire drafted by the researcher. The questionnaire has section A, B and C. section A has 5 items which took a look at extent democratic leadership of principals enhance institutional practice and goal achievement among secondary schools. section B has 4 items and focused on extent autocratic virtues of the principal enhance institutional practice and goal achievement while section $\mathrm{C}$ has 6 items and focused on the extent laisser-faire virtues of the principal enhance institutional practice and goal achievement among secondary schools. was validated by three experts. The reliability coefficient was determined using Cronbach Alpha reliability coefficient technique which gave coefficient of $0.76,0.69$, and 0.75 for the three clusters amounting to a total of 0.73. Arithmetic Mean and standard deviation were used as analysis tool. While t-test was used to test the hypothesis.

\section{Results}

- Research Question One: To what extent does democratic leadership enhance institutional practice and goal achievement among secondary schools? 


\begin{tabular}{|c|c|c|c|c|c|}
\hline S/N & ITEMS & $\mathbf{N}$ & $\overline{\mathbf{X}}$ & $\mathbf{S A}$ & Decision \\
\hline 1 & $\begin{array}{c}\text { Extent the school head delegates duties } \\
\text { to other teachers }\end{array}$ & 173 & 2.65 & 0.54 & Accept \\
\hline 2 & $\begin{array}{c}\text { Extent head teachers works with } \\
\text { teachers }\end{array}$ & 173 & 2.84 & 0.56 & Accept \\
\hline 3 & $\begin{array}{c}\text { Extent principals involves teaching staff } \\
\text { in decision making }\end{array}$ & 173 & 3.21 & 0.43 & Accept \\
\hline 4 & $\begin{array}{c}\text { What extent do principals work } \\
\text { according to school rules }\end{array}$ & 173 & 3.30 & 0.43 & Accept \\
\hline 5 & $\begin{array}{c}\text { The extent your school leader over use } \\
\text { democratic virtues in his daily affairs }\end{array}$ & 173 & 2.23 & 0.50 & Reject \\
\hline
\end{tabular}

Table 1: Extent Democratic Leadership Enhances Institutional Practice and Goal Achievement

Analysis in table 1 above shows that the mean scores from item 1-5 were 2.65, 2.84, 3.21, 3.30 and 2.23 respectively. Item 5 was rejected because the mean score is below 2.50. Other items were accepted because their mean score was 2.50 and above.

- Research Question Two: To what extent does autocratic leadership enhance institutional practice and goal achievement among secondary schools?

\begin{tabular}{|c|c|c|c|c|c|}
\hline $\mathbf{S} / \mathbf{N}$ & ITEMS & $\mathbf{N}$ & $\overline{\mathbf{X}}$ & $\mathbf{S D}$ & Decision \\
\hline 1 & $\begin{array}{c}\text { The extent your school leader } \\
\text { makes decision alone }\end{array}$ & 173 & 1.63 & 0.87 & Reject \\
\hline 2 & $\begin{array}{c}\text { Extent your school head dictates } \\
\text { what happens in your school }\end{array}$ & 173 & 2.31 & 0.50 & Reject \\
\hline 3 & $\begin{array}{c}\text { Extent teachers are allowed to air } \\
\text { their views on opinions }\end{array}$ & 173 & 2.93 & 0.66 & Accept \\
\hline 4 & $\begin{array}{c}\text { Extent your school leader share } \\
\text { responsibilities to teachers }\end{array}$ & 173 & 3.01 & 0.40 & Accept \\
\hline
\end{tabular}

Table 2: Extent Autocratic Leadership Enhances Institutional Practice and Goal Achievement

Analysis in table 2 above shows that the mean scores from item 1-7 were 1.63, 2.31, 2.93 and 3.01 respectively. Items 1 and 2 were rejected because their mean score is below 2.50. Other items were accepted because their mean score was 2.50 and above.

- $\quad$ Research Question Three: To what extent does laisser-fair leadership enhance institutional practice and goal achievement among secondary schools?

\begin{tabular}{|c|c|c|c|c|c|}
\hline S/N & ITEMS & $\mathbf{~ N}$ & $\overline{\mathbf{X}}$ & $\mathbf{S A}$ & Decision \\
\hline 1 & $\begin{array}{c}\text { What extent do your school principal } \\
\text { participate in PTA meeting }\end{array}$ & 173 & 3.05 & 0.40 & Accept \\
\hline 2 & $\begin{array}{c}\text { What extent do your headteacher } \\
\text { participates in internal supervision }\end{array}$ & 173 & 2.60 & 0.54 & Accept \\
\hline 3 & $\begin{array}{c}\text { Extent of monitoring of dilapidated } \\
\text { structures in your school }\end{array}$ & 173 & 3.06 & 0.40 & Accept \\
\hline 4 & $\begin{array}{c}\text { The extent your school leader comes to } \\
\text { school }\end{array}$ & 173 & 2.07 & 0.51 & Reject \\
\hline 5 & $\begin{array}{c}\text { What extent do your principal disciplines } \\
\text { teachers }\end{array}$ & 173 & 2.31 & 0.52 & Reject \\
\hline 6 & $\begin{array}{c}\text { What extent is your principal our spoken } \\
\text { on sensitive issues }\end{array}$ & 173 & 3.23 & 0.41 & Accept \\
\hline
\end{tabular}

Table 3: Extent Laisser-Fair Leadership Enhances Institutional Practice and Goal Achievement

Analysis in table 3 above shows that the mean scores from item 1-6 were 3.05, 2.60, 3.06, 2.07, 2.31 and 3.23 respectively. Items 4 and 5 were rejected because their mean score is below 2.50. Other items were accepted because their mean score was 2.50 and above. 


\subsection{Testing of Hypothesis}

\subsubsection{Hypothesis 1}

- $\mathrm{H}_{0}$ : Opinions of male and female teachers do not significantly differ on extent leadership enhance institutional practice and goal achievement among secondary schools

\begin{tabular}{|c|c|c|c|c|c|c|c|c|}
\hline Respondents & $\mathbf{N}$ & SD & $\mathbf{X}$ & t-cal & df & $\boldsymbol{\alpha}$ & T-crit & Decision \\
\hline Female & 144 & 0.84 & 0.74 & & & & & \\
\hline & & & & 0.163 & 171 & .05 & 1.972 & Accept $\mathrm{H}_{0}$ \\
\hline Male & 29 & 0.31 & 0.28 & & & & & \\
\hline
\end{tabular}

Attitude and Commitment towards Continuous Assessment

On the table 4 above, t-cal (0.163) is less than t-crit (1.972). accept null hypothesis.

\section{Discussion}

Table one sought the extent democratic leadership enhances institutional practices and goal achievement. Findings reveal that to a high extent, school heads share certain duties to their teachers, work with them and allow the entire teaching staff actively involved in decision making. It was also revealed that secondary school principals work according to established roles in school. Similar to these findings, Kamurua (2013) reported that in a democratic institution, workers are highly motivated by their involvement in the setting of goals, improving methods and appraising progress towards goals of the organization. There is good employee management relationship and workers see themselves as part of the organization by exhibiting high degree of responsibility and commitment. Anuna (2010) asserts that principals who use democratic leadership facilitate the mission of the school which must be hierarchical. It also increases morale by making the staff and student feel valued.

Tale two sought the extent autocratic leadership enhances institutional practices and goal achievement. Findings show that to a high extent, teachers are allowed to air their views and that school leaders share responsibilities among teachers but to a low extent, school leaders make decisions alone and dictates what happens in school. This means that principals of secondary schools and other schools' leaders of secondary schools understood that autocracy has negative influence on work production. This corroborates Ochieng cited in Kanurua (2013) whose findings at secondary schools in Mombasa found that autocracy leads to exhibition of poor input to work by teachers which in-turn, leads to poor performance among students. Therefore, McLean, Fairman and Moore (2006), warns against this type of leadership behaviour as leaders of successful schools emphasize consultation, teamwork and participation leadership that influence establishment of a positive school behavior.

Table three sought the extent laisser-fair leadership enhances institutional practices and goal achievement. Findings show that to a high extent, school principals participate in Parent Teacher Association (PTA), internal supervision as well as monitors the school to ascertain dilapidated structures. These findings portray that principals of secondary schools in Enugu state are not lazy as against qualities of laziness enunciated by MacDonald's (2007) in Kanurua (2013) whose study on laisser-faire leadership shows that it is associated with the highest rates of truancy and delinquency and with the slowest modifications in performance which lead to unproductive attitudes. Again, Pasi (2007), in a study on school leadership and its influence on performance showed a negative correlation between the laissez-faire leadership style and the school performance in secondary schools in Tanzania.

\section{Conclusion}

Educational leadership in schools that yields best practices and achievement of goals demands quality and cooperative leadership styles among leaders in a school.

\section{Recommendations}

Based on the findings from this research, the study recommends that;

- To a high extent, leaders in secondary schools be constantly engaged in re-training exercise to maintain educational leadership in their various schools.

- Teachers also need to be re-trained on implementation of educational leadership in schools since they are implementers of the curriculum in classrooms.

- Incentives needed for this implementation such as human and material resources should be made available to school leaders when needed.

\section{References}

i. Akanni, Olubukola Olutosin. (2019). evaluation of teachers' attitude and competence towards implementation of continuous assessment among adolescents in Ifako Ijaye Local Government Area. Education \& Science Journal of Policy Review and Curriculum Development, 9 (2)12-25

ii. $\quad$ Alumode (2012).Communication in Staff Management. Ibadan: Paperback Publishers Limited.

iii. Anuna, M.C (2004). Educational Supervision: The Nigerian Experience. Enugu, Vantage Publishers.

iv. Aurora-Tatiana Dina (2013). Challenges faced by educational leadership on influencing student learning. Procedia-social and Behavioural Science 93, 290-295. 
v. Ezenwekwe, M. C. (2013). Teacher-principal communication patterns as correlates of effective school administration in public secondary schools in Onitsha Education Zone of Anambra State. A thesis on Degree of Masters, Department of Educational Foundations, University of Nigeria, Nsukka.

vi. Federal Republic of Nigeria (2004). National Policy on Education. Abuja: Federal Ministry of Education.

vii. Garcia, Q. P., \& Santiago, A. B. (2017). Parenting styles as correlates to self-esteem of underprivileged adolescents: Basis for a proposed parenting skills program. International Journal of Advanced Education and Research, 2(5), 27-35.

viii. Louis, J. B (2017). Factors that influence student behaviour in secondary schools. European Journal of Educational and Development Psychology, 5 (5) 27-36

ix. Kamurua, M. W (2013). Influence of principal's leadership styles in establishing school climate in secondary schools in Manindi District. Unpublished M.Ed. thesis, department of Educational Administration, University of Nairobi

x. $\quad$ McLean L., Fairman, M. and Moore, B. (2006) A System Approach to Charting a Path to Quality and Achievement. Report no. 1 to the The Council of Chief School Officer's (Successful Practices Series).

xi. Ministry of Education and Human Resource. (2014). Education reforms in actions: 2008- 2014. Phoenix: IVTB House.

xii. Okeze, W. O., Okpe, P. U., and Ngwakwe, E. J (2018). Assessment of financial management practices of secondary schools in Abia State. Journal of Economics and Environmental Education, 3 (1) 33-46

xiii. Schermerhorn, J. R., Hunt, J.G. \& Osborn, R. N. (2000). Organisational Behaviour. 7th Edition. New York: John Wiley \& Sons Inc.

xiv. Temesgen, S. A.(2017) Teachers' Perception and Practices Towards Continuous Assessment of Mathematics Classes: The Case of Secondary School in Wolaita Zone, Snnpr Region. Journal of Education and Practice, 2 (22) 84-109.

xv. Wikipedia (2020) educational leadership in https://en.m.wikipedia.org/wiki/educational_leadership 